\title{
Effects of antecedent soil moisture on runoff modeling in small semiarid watersheds of southeastern Arizona
}

\author{
Y. Zhang ${ }^{1}$, H. Wei ${ }^{2}$, and M. A. Nearing ${ }^{3}$ \\ ${ }^{1}$ College of Soil and Water Conservation, Beijing Forestry University, Beijing, China \\ ${ }^{2}$ University of Arizona, Tucson, AZ, USA \\ ${ }^{3}$ Southwest Watershed Research Center, USDA Agricultural Research Service, 2000 E. Allen Rd., Tucson, AZ, 85719, USA
}

Received: 17 June 2011 - Published in Hydrol. Earth Syst. Sci. Discuss.: 28 June 2011

Revised: 19 September 2011 - Accepted: 22 September 2011 - Published: 18 October 2011

\begin{abstract}
This study presents unique data on the effects of antecedent soil moisture on runoff generation in a semi-arid environment, with implications for process-based modeling of runoff. The data were collected from four small watersheds measured continuously from 2002 through 2010 in an environment where evapo-transpiration approaches $100 \%$ of the infiltrated water on the hillslopes. Storm events were generally intense and of short duration, and antecedent volumetric moisture conditions were dry, with an average in the upper $5 \mathrm{~cm}$ soil layer over the nine year period of $8 \%$ and a standard deviation of $3 \%$. Sensitivity analysis of the model showed an average of $0.05 \mathrm{~mm}$ change in runoff for each $1 \%$ change in soil moisture, indicating an approximate $0.15 \mathrm{~mm}$ average variation in runoff accounted for by the $3 \%$ standard deviation of measured antecedent soil moisture. This compared to a standard deviation of $4.7 \mathrm{~mm}$ in the runoff depths for the measured events. Thus the low variability of soil moisture in this environment accounts for a relative lack of importance of storm antecedent soil moisture for modeling the runoff. Runoff characteristics simulated with a nine year average of antecedent soil moisture were statistically identical to those simulated with measured antecedent soil moisture, indicating that long term average antecedent soil moisture could be used as a substitute for measured antecedent soil moisture for runoff modeling of these watersheds. We also found no significant correlations between measured runoff ratio and antecedent soil moisture in any of the four watersheds.
\end{abstract}

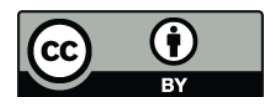

Correspondence to: M. A. Nearing (mark.nearing@ars.usda.gov)

\section{Introduction}

Soil water content in the upper soil layer prior to a rain event can be an important factor affecting the relationship between rainfall and runoff (Yair and Klein, 1973; Abrahams et al., 1988; Karnieli and Ben-Asher, 1993; MartinezMena et al., 1998; Castillo et al., 2003; Zehe et al., 2005; James and Roulet, 2009; Brocca et al., 2009a, b; Penna et al., 2011; Tramblay et al., 2010; Kampf, 2011). Western et al. (1998) analyzed relationships between watershed average soil moisture derived from point measurements and daily runoff coefficient for days with rainfall greater than $5 \mathrm{~mm}$ for the 10.5 ha semi-humid Tarrawarra watershed characterized by a silt loam soil type. Their results showed that the surface runoff was strongly controlled by soil moisture, with a threshold value of the volumetric water content varying from 41 to $46 \%$, below which no runoff occurred. Similarly, another study conducted by Brocca et al. $(2004,2005)$ on a semi-humid watershed $\left(12.9 \mathrm{~km}^{2}\right)$ with sandy loam soils in central Italy indicated that only when antecedent volumetric soil moisture content was above approximately $36 \%$ were the runoff coefficients generally greater than zero.

In hot semiarid and arid environments soils are often much drier in general, and the role of antecedent soil moisture can be less important. Castillo et al. (2003) attributed this to the controlling runoff mechanism of infiltration excess overland flow, as contrasted to saturation excess. By conducting a stochastic sensitivity analysis on the runoff response to different soil moisture scenarios using a physically based distributed model in semiarid Spain, Castillo et al. (2003) drew the conclusion that "when infiltration excess overland flow is predominant, as a result of high rain intensities or less permeable soils, the runoff response... does not depend on initial

Published by Copernicus Publications on behalf of the European Geosciences Union. 
soil moisture. Runoff from less intense storms on soils of higher permeability is controlled by the soil water content of the surface soil layers and is more dependent on initial conditions".

Several studies have examined the effect of antecedent soil moisture on runoff simulation in physically based models (Goodrich et al., 1994; Castillo et al., 2003; Zehe and Blöschl, 2004; Brocca et al., 2008; Sheikh et al., 2010). Goodrich et al. (1994) found that runoff volumes and peak rates were not particularly different using antecedent soil moisture as calculated with spatially averaged remotely sensed data vs. a simple daily soil moisture model at the small (4.4 ha) and medium (631 ha) watershed scales in semiarid southeastern Arizona, USA. Brocca et al. (2008) investigated the reliability of a new and different structure for a soil water balance model (incorporating the Green-Ampt infiltration model) to be used as a component of an event-based rainfall-runoff model (Brocca et al., 2011a, 2011b). For testing the reliability of the soil water balance model, Brocca et al. (2008) compared the "observed" and computed soil water content before several rainfall events (greater than $5 \mathrm{~mm}$ ) of their test period (September 2003-May 2004). Their results showed that $90 \%$ of the cases had an absolute error of computed soil water content less than $15 \%$. Moreover, the correlation $\left(r^{2}=0.80,0.88\right.$ for runoff depth and peak discharge, respectively) between runoff observed and estimated with a multiple linear regression incorporating modeled soil water was similar to that found $\left(r^{2}=0.79,0.91\right.$ for runoff depth and peak discharge, respectively) using observed soil water contents. Using two storm events in two burnt watersheds (7.56 and $6.38 \mathrm{ha}$ ) and one un-burnt watershed (24.28 ha) in semiarid Spain, Castillo et al. (2003) found that the sensitivity of modeled runoff response to soil moisture depended on the rainfall amount. The modeled hydrological response after the high intensity, low frequency storm was independent of the initial soil water content; while the antecedent soil water content was an important factor controlling modeled runoff from the medium to low intensity storms.

Among the factors which govern infiltration, including rainfall, soil properties, and vegetation, antecedent soil moisture data prior to each rainfall event is often the most uncertain and least easily available (Karnieli and Ben-Asher, 1993). Soil water content monitoring at the watershed scale is difficult because of its space-time variability and because field measurements are costly and time consuming (Brocca et al., 2008). Soil moisture tracking models are often used, but uncertainty associated with any model parameter, including soil moisture, will generate uncertainty in model response (Nearing and Hairsine, 2011). Thus, the task of runoff modeling confronts the dilemma of determining how much emphasis should be placed on defining precise values of antecedent soil moisture as one of the model initial conditions due to both its effects on runoff response (model sensitivity) and its uncertainty and unavailability.
Because there are very few studies that have looked at the effects of antecedent soil moisture on runoff modeling sensitivities in arid/semi-arid areas, the objectives of this study were: (1) to examine the sensitivity of the measured runoff to rainfall ratio to measured antecedent soil water content, (2) to analyze the sensitivity of runoff depth and peak model output to soil moisture input, and (3) to test the prediction capability of runoff at a small watershed scale using measured storm-antecedent soil moisture vs. long-term average antecedent soil water content for model initial conditions using the Green-Ampt Mein-Larson model (Mein and Larson, 1973) for unsteady intermittent rainfall (Chu, 1978) within the Rangeland Hydrology and Erosion Model (RHEM) (Nearing et al., 2011). A 9-yr record of measured rainfall, runoff, and soil moisture data from four small semiarid rangeland watersheds in southern Arizona, USA ranging in size from 0.34 to 4.53 ha were used.

\section{Methods}

\subsection{Description of the experimental watersheds}

This study was conducted using data from four small watersheds located on the Walnut Gulch Experimental Watershed near Tombstone in southeastern Arizona, USA, which is operated by the United States Department of Agriculture (USDA) Agricultural Research Service (ARS) Southwest Watershed Research Center (Moran et al., 2008). The climate of the area is semiarid with annual precipitation of approximately $350 \mathrm{~mm}$ and highly spatially and temporally varying precipitation patterns dominated by the North American Monsoon (Renard et al., 2008). Monsoon storms are typically characterized as short-duration, high-intensity, localized rainfall events. Two thirds of the annual precipitation falls during the "monsoon" season from July through midSeptember, and much of the remainder is concentrated in the winter months of December through February (Nichols et al., 2002). The channels in Walnut Gulch Experimental Watershed are dry most of the time (Nearing et al., 2007). Mean annual temperature in the Walnut Gulch Experimental Watershed measured is $17.7^{\circ} \mathrm{C}$, and the average monthly maximum temperature of $35^{\circ} \mathrm{C}$ occurs in June, with average monthly minimum temperature of $2{ }^{\circ} \mathrm{C}$ in December (Nichols et al., 2002).

The hydrology of this area is characterized by very high evaporation rates under relatively dry conditions. Of the $350 \mathrm{~mm}$ of average annual rainfall, $327 \mathrm{~mm}$ infiltrates into the soil and $23 \mathrm{~mm}$ runs off the hillslopes into first order channels. Essentially $100 \%$ of the $327 \mathrm{~mm}$ of water on the hillslope is lost to evapo-transpiration, and there is essentially no subsurface return flow to channels (Renard et al., 2008). The channels themselves are "losing streams", and are characterized by transmission losses as the water moves downstream, rather than having a gain in flow. The soils are 
characterized by a calcium carbonate (caliche) layer at approximately $60 \mathrm{~cm}$, which is further evidence of the fact that there is no subsurface drainage in these watersheds. Furthermore, the soils themselves dry very quickly under the high ET conditions, and the storms that cause runoff, the monsoon storms, are always of short duration and high intensity. As a result, infiltration into these soils tends to be to very shallow depths, and hence any effect of antecedent moisture would be related to the moisture in the very top layer of soil. For this reason in this study we report the moisture in the top $5 \mathrm{~cm}$ of soil as the indicative antecedent soil moisture, rather than the $15 \mathrm{~cm}$ depth as is often done for studies in wetter environments.

The four watersheds (i.e. Watershed 63.102, 63.103, 63.104 and 63.106) were located in what is referred to as "Lucky Hills" (Table 1 and Fig. 1) and ranged in size from 0.34 to 4.53 ha. Watersheds 63.102 and 63.106 are nested within 63.104 . The vegetation in this area is dominated by desert shrub (mainly creosote and whitethorn) with canopy cover during the rainy season of approximately $25 \%$ (Nearing et al., 2007). The elevation of the area is approx. $1360 \mathrm{~m}$ a.s.l.

The soil in the Lucky Hills shrub area is a gravelly sandy loam with approximately $52 \%$ sand, $26 \%$ silt, and $22 \%$ clay. The organic carbon content of the soils is low (generally less than $1 \%$ ) (Nearing et al., 2007).

Watersheds 63.102, 63.103 and 63.104 are drained by well-developed, incised channel networks that efficiently deliver eroded particles to the watershed outlets (Nearing et al., 2005). Watershed 63.106 is smaller than the others and does not have a highly incised channel, but as with the other three also does not have a toe-slope area of noticeable deposition and sediment storage (Polyakov et al., 2009).

\subsection{Instrumentation and data collection}

All of the data for precipitation, rainfall, runoff, and soil moisture used in this study are available for public download through the Data Access Project at the USDA-ARS Southwest Watershed Research Center (http://www.tucson.ars.ag. gov/dap/; Nichols and Anson, 2008). Runoff was measured with calibrated, Santa Rita-supercritical flumes at the outlets of watersheds 63.102, 63.103, and 63.104, an H-flume at watershed 63.106 (Stone et al., 2008). Digital recorders consisting of potentiometers attached to the stilling well gear mechanisms and data loggers were used to record discharge depth (Stone et al., 2008).

88 rain gages are currently in operation within or adjacent to the $150 \mathrm{~km}^{2}$ Walnut Gulch Experimental Watershed. Rainfall measured with digital gage 83 was used (Fig. 1). The precipitation record observed via the digital gages consists of rainfall depths at $1 \mathrm{~min}$ intervals during periods of rainfall (Goodrich et al., 2008).

Soil moisture was measured with a single sensor at a depth of $5 \mathrm{~cm}$ at 19 rain gages across the watershed since 2002. In
Table 1. Characteristics of the watersheds in which rainfall, runoff and soil moisture were measured and used in this study.

\begin{tabular}{lrr}
\hline Watershed & Area & Average slope steepness \\
\hline & ha & $\%$ \\
63.102 & 1.46 & 10.5 \\
63.103 & 3.68 & 7.8 \\
63.104 & 4.53 & 10.5 \\
63.106 & 0.34 & 8.9 \\
\hline
\end{tabular}

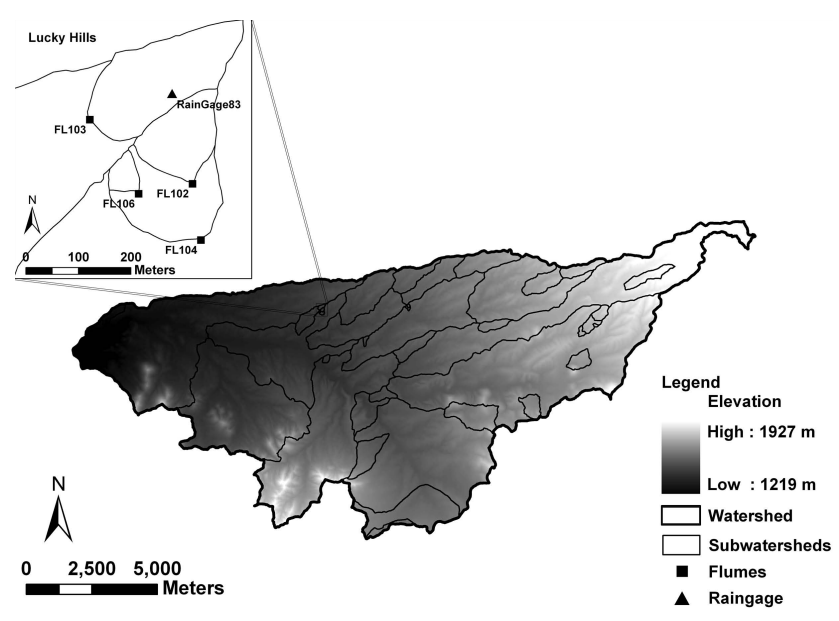

Fig. 1. Map of Walnut Gulch watershed with locations of watersheds and instrumentation used in this study. Soil moisture sensors were located near rain gages 82 and 83 .

2002 soil moisture was sampled and reported every $30 \mathrm{~min}$, but $20 \mathrm{~min}$ intervals were used since 2003 (Keefer et al., 2008). Soil moisture measured near rain gage 83 was used.

\subsection{Data and analyses}

Data were compiled for the four watersheds for the period of 2002-2010. The data sets collected included: (1) breakpoint rainfall; (2) runoff dates, times, durations, total storm-runoff volumes and peak runoff rates; and (3) volumetric soil water content of the upper $5 \mathrm{~cm}$ soil layer, including dates, times and soil moistures. The upper $5 \mathrm{~cm}$ soil water is used because in this environment only the very top layer of soil usually is wet during an event and dries quickly in summer, when most runoff occurs. Rainfall and runoff were matched with each other based on their start and end times. Antecedent soil moisture was matched to each rainfall event with the moisture recorded within $30 \mathrm{~min}$ before rainfall started. Daily rainfall depths and daily average moistures were computed using rainfall event data and averaged volumetric soil water content records with $20 \mathrm{~min}$ or $30 \mathrm{~min}$ intervals.

Other data gathered for running RHEM included soil and vegetation properties such as texture, bulk density, porosity, 
canopy cover, ground cover, and geomorphologic parameters such as average slope length and slope gradient. That information was obtained from previous studies (Nearing et al., 2007, 2011; Wei et al., 2007).

\subsection{Analysis of measured runoff ratio as influenced by antecedent soil moisture}

Runoff to rainfall ratios of events from the four small watersheds during 2002 to 2010 were calculated and matched to measured antecedent soil moisture. Linear correlation coefficients and scatter plots with the confidence ellipses of correlations were used to test the relationship between measured runoff ratio and antecedent soil moisture and to check if there is an observable threshold value of antecedent soil moisture that controlled the presence or absence of runoff.

\subsection{RHEM Model parameterization and calibration}

The Rangeland Hydrology and Erosion Model (RHEM) was used (Nearing et al., 2011), in which infiltration was computed using the Green-Ampt Mein-Larson model (Mein and Larson, 1973) for unsteady intermittent rainfall as modified by Chu (1978). RHEM is an event-based derivation of the WEPP model, incorporating new equations derived from rangeland data (Wei et al., 2009). RHEM represents hydrology and erosion processes under disturbed and undisturbed rangeland conditions and it links the model hydrologic and erosion parameters with rangeland plant communities. The model details can be found in Nearing et al. (2011).

The model parameters for infiltration and runoff simulation include the Green-Ampt effective hydraulic conductivity, $K_{\mathrm{e}}$, effective matric potential, $\psi$, and Darcy-Weisbach friction factor for runoff, $f$. In this study, $\psi$ and $f$ were calculated using the default methods for RHEM as described by Nearing et al. (2011), and runoff volumes were used to calibrate the model for the value of $K_{\mathrm{e}}$ for each watershed. Effective hydraulic conductivity $\left(K_{\mathrm{e}}\right)$ values were calibrated using the nine year period of measured rainfall, runoff, and soil moisture data. One hundred and eighty six rainfallrunoff events from watersheds 63.102, 63.103, 63.104 and 63.106 during the period of 2002-2010 were used (Table 2). Note that not every watershed had runoff for every event, thus the 186 measured runoff hydrographs for the 60 events. During the calibration, runoff was simulated by RHEM with different $K_{\mathrm{e}}$ values ranging from 0.8 to $40 \mathrm{~mm} \mathrm{~h}^{-1}$ with increments of $0.1 \mathrm{~mm} \mathrm{~h}^{-1}$. The calibrated $K_{\mathrm{e}}$ for each watershed was obtained by maximizing the Nash-Sutcliffe model efficiency, $E$ (Nash and Sutcliffe, 1970). During the calibration, measured antecedent soil moisture for each event was used as the RHEM input.

Physical characteristics of the watershed needed included soil porosity, $\eta$, slope length, and slope gradient. Slope lengths and gradients were calculated using DEMs (Digital elevation models) with $1 \mathrm{~m}$ resolution based on LIDAR mea- surements. Soil porosity input was based on measured soil bulk densities.

\subsection{Sensitivity analysis}

Model sensitivity is the variation or change in a model response as a function of change in one or more model input parameters. Sensitivities of simulated storm-runoff volumes and peaks to antecedent soil moisture were analyzed by changing the input value of antecedent soil saturation ratio (volumetric soil water content divided by soil porosity) from $0 \%$ to $48 \%$ with increments of $3 \%$, corresponding to a range in volumetric soil moisture content from $0 \%$ to $22.4 \%$ with increments of $1.32 \%$, based on the range of recorded soil moisture. Sixty rainfall-runoff events from each of watersheds during the period of 2002 through 2010 were simulated with the 18 antecedent soil moisture values.

The local Sensitivity Index (SI), also termed as the "one factor at a time", was used in this study. The local SI measures the partial derivative of $Y$ with respect to $x_{i}$ at point $x^{0}$ (Saltelli and Campolongo, 2000), and thus it quantifies the local model response $(Y)$ to any given input parameter $\left(x_{i}\right)$ at any point $x^{0}$ within the full input parameter space for the model. SI is defined by the equation:

$\left\{\frac{\partial Y}{\partial x_{i}}\right\}_{x^{0}}=\frac{Y\left(x_{1}^{0}, \ldots, x_{i}^{0}+\partial x_{i}, \ldots, x_{I}^{0}\right)-Y\left(x^{0}\right)}{\partial x_{i}}$

where $I$ is the total number of input parameters. In this study, we were interested only in the sensitivity of model response to the parameter $x_{i}$ that represented antecedent soil moisture, and SI was calculated based on incremental (step) changes in the value of volumetric soil moisture. Thus magnitude of SI in this study represents the change of runoff $(\mathrm{mm})$ caused by each $1 \%$ change of volumetric soil moisture $\left(\Delta Y / \Delta x_{i}\right)$.

\subsection{Use of long-term average antecedent soil moisture as model input for each storm}

As an alternative to using measured antecedent soil moisture for each storm, this study tested the predictability of runoff using the long term average antecedent soil water content as a substitute for measured soil moisture prior to each rainfall event. With calibrated $K_{\mathrm{e}}$, runoff volumes and peak rates of 186 events in the four watersheds were simulated using long term average (2002-2010) antecedent soil moisture for each event as the model input (not every watershed experienced runoff for each of the 60 events). In order to further examine the effect of antecedent soil moisture on runoff, Nash-Sutcliffe model efficiency, $E$, and coefficient of determination $r^{2}$, between measured runoff volume and simulated runoff volume with long term average antecedent soil moisture were calculated and compared with the $E$ and $r^{2}$ between measured runoff volume and simulated runoff volume with event measured antecedent soil moisture as the model input. Linear regression was used to compare between runoff 
Table 2. Calibrated Green-Ampt Effective Hydraulic Conductivities, $K_{\mathrm{e}}$, for the four watersheds in Lucky Hills.

\begin{tabular}{llllll}
\hline Watershed & $\begin{array}{l}\text { Number } \\
\text { of events }\end{array}$ & $\begin{array}{l}\text { Measured } \\
\text { runoff volume }\end{array}$ & $\begin{array}{l}\text { Calibrated } \\
K_{\mathrm{e}}\end{array}$ & $\begin{array}{l}\text { Nash-Sutcliffe } \\
\text { model efficiency, } E\end{array}$ & $\begin{array}{l}\text { Coefficient of } \\
\text { Determination, } r^{2}\end{array}$ \\
\hline 63.102 & 45 & $0.1-17.1$ & 5.7 & 0.737 & \\
63.103 & 46 & $0.0-20.7$ & 4.6 & 0.752 & 0.855 \\
63.104 & 39 & $0.0-13.1$ & 7.5 & 0.627 & 0.855 \\
63.106 & 56 & $0.1-22.8$ & 2.7 & 0.810 & 0.817 \\
\hline
\end{tabular}

volumes and peaks simulated with long term average antecedent soil moisture and event measured antecedent soil moisture.

\section{Results and discussion}

\subsection{Characteristics of precipitation, runoff and soil moisture}

Annual measured precipitation at Lucky Hills during the period of study (2002-2010) ranged between 189 and $389 \mathrm{~mm}$ with a maximum recorded $24 \mathrm{~h}$ rainfall of $52 \mathrm{~mm}$ (Fig. 2). There were 60 rainfall-runoff events recorded in Lucky Hills that could be matched with antecedent soil moisture from 2002 to 2010 and a total of 186 runoff hydrographs (not every watershed had runoff for every rainfall event) were recorded from the four small watersheds, with the maximum runoff depth for each watershed ranging from $13.1 \mathrm{~mm}$ to $22.8 \mathrm{~mm}$ (Table 2). The average event runoff depth for the entire data set was $4.3 \mathrm{~mm}$, with a standard deviation of $4.7 \mathrm{~mm}$. Average daily soil moisture measured during 2002 to 2010 was $3.6 \%$, with a maximum measured value of $21.3 \%$ and median value of $2.4 \%$.

\subsection{Relationships between measured runoff ratios and antecedent soil moisture}

Measured runoff to rainfall ratios for the 186 runoff hydrographs ranged from $0 \%$ to $60.6 \%$ with a mean of $18.5 \%$. Antecedent volumetric soil moisture immediately prior to the measured 60 rainfall events ranged from $1 \%$ to $17 \%$, with an average of $8.0 \%$ and a standard deviation of $3.0 \%$ (Fig. 3). There was no significant correlation $(\alpha=0.05)$ between runoff ratio and antecedent soil moisture in any of the four watersheds, with Pearson's correlation coefficients ranging from 0.10 to 0.15 (Fig. 4).

\subsection{Simulation of runoff with measured antecedent soil moisture}

Calibrated values of $K_{\mathrm{e}}$ for the four watersheds in Lucky Hills are given in Table 2. Figure 5 shows the relationships

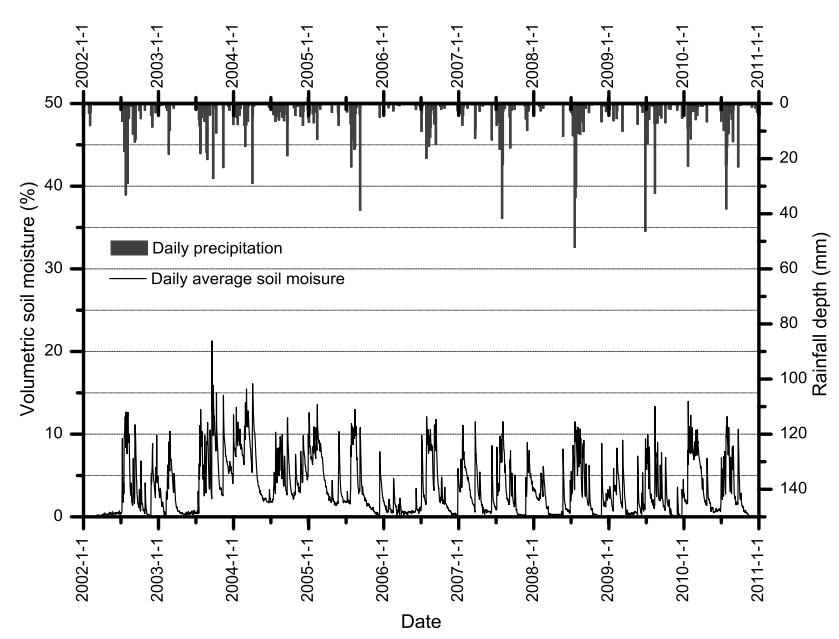

Fig. 2. Daily precipitation and daily average volumetric soil moisture in Lucky Hills from 2002 to 2010.

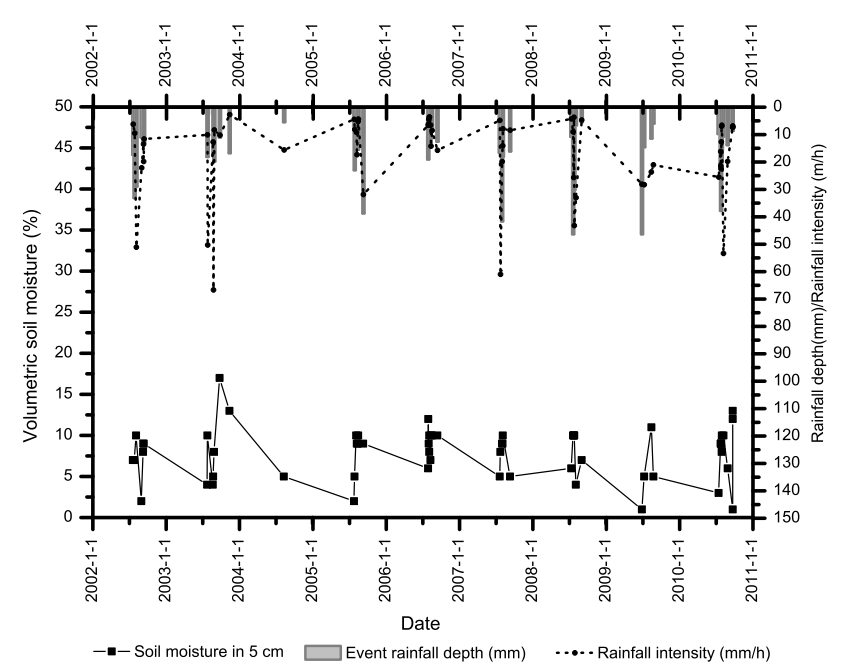

Fig. 3. Rainfall and volumetric antecedent soil moisture of all the 60 rainfall events recorded in Lucky Hills from 2002 to 2010. 

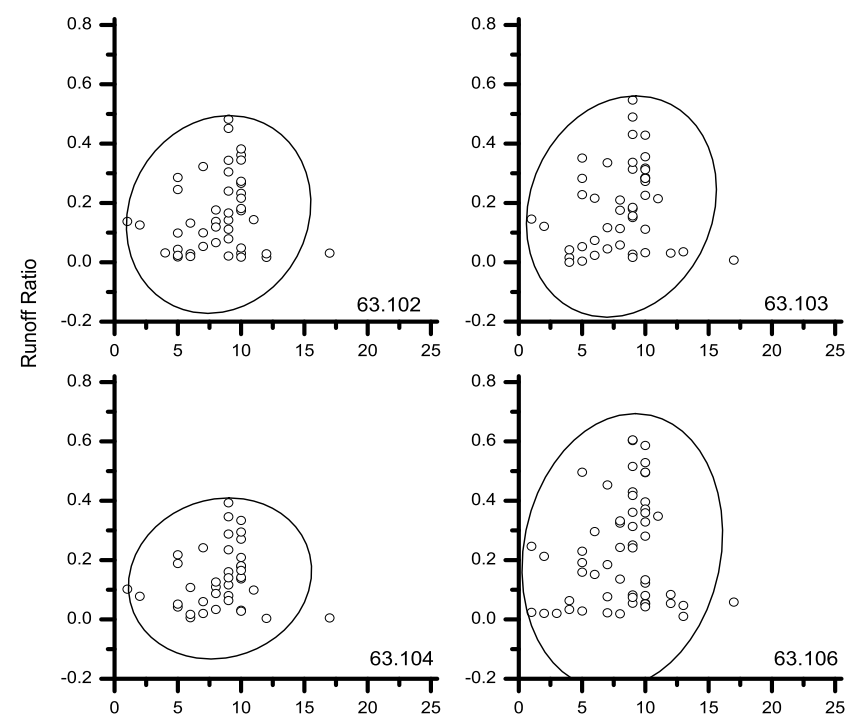

Antecedent volumetric soil moisture in $5 \mathrm{~cm}(\%)$

$-95 \%$ confidence ellipse

Fig. 4. Correlations between measured runoff ratio and measured antecedent soil moisture from the four watersheds $(63.102,63.102$, 63.104 and 63.106) in Lucky Hills from 2002 to 2010. The confidence ellipse collapses diagonally as the correlation between two variables approaches 1 or -1 . The confidence ellipse is more circular when two variables are uncorrelated.

between the model input value of $K_{\mathrm{e}}$ as a function of model efficiency, $E$, from which the best estimations of $K_{\mathrm{e}}$ were determined (Table 2). Linear regressions between measured and model predicted runoff volumes using the calibrated $K_{\mathrm{e}}$ values produced $r^{2}$ values ranging from 0.82 to 0.88 and $E$ values ranging from 0.63 to 0.81 (Table 2 ). There was no observable systematic bias between simulated and measured runoff volumes (Fig. 6).

\subsection{Sensitivity of simulated runoff to antecedent soil moisture}

The average SI of simulated runoff volume to antecedent soil moisture $\left(\mathrm{SI}_{Q}\right)$ indicated a change in runoff depth of $0.05 \mathrm{~mm}$ for each $1 \%$ change in antecedent volumetric soil moisture. Given that the standard deviation in the antecedent volumetric soil moisture was $3 \%$, the amount of variation attributable to the variation in soil moisture was of the order of 3 multiplied by 0.05 , or $0.15 \mathrm{~mm}$. As mentioned previously, the average runoff depth for the entire data set was $4.3 \mathrm{~mm}$, with a standard deviation of $4.7 \mathrm{~mm}$. The variation in soil moisture for these data could only have constituted a small portion of the overall runoff variance.
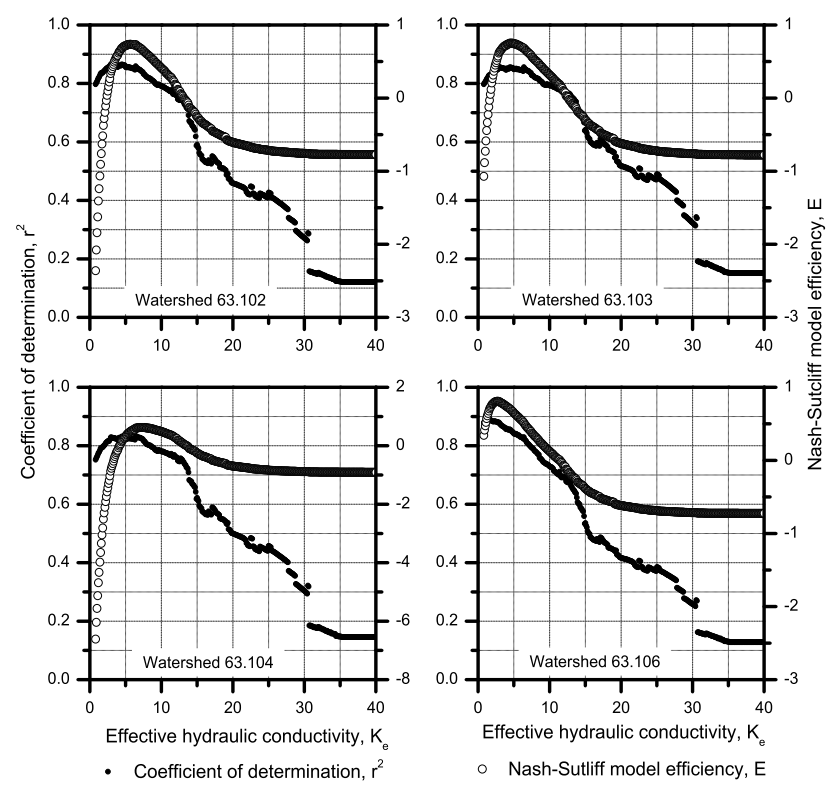

Fig. 5. Coefficients of determination and Nash-Sutcliff model efficiencies of the linear relationships between simulated and measured runoff volumes as a function of model input values of effective hydraulic conductivity $K_{\mathrm{e}}$ for calibration in Lucky Hills.

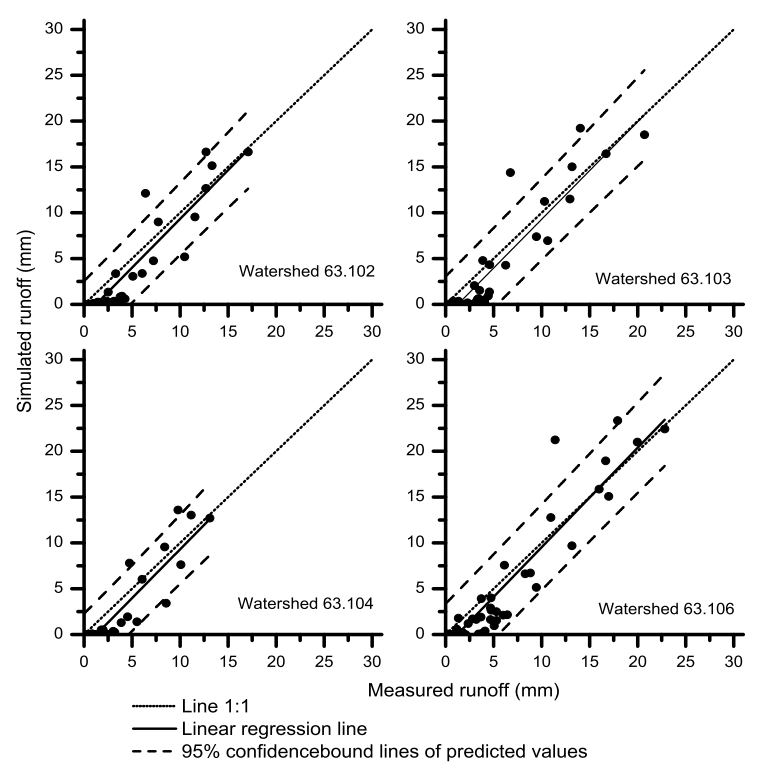

Fig. 6. Comparison of simulated runoff with measured runoff in the four watersheds in Lucky Hills.

\subsection{Runoff simulation with average antecedent soil moisture as a substitute for measured daily antecedent soil moisture}

The Nash-Sutcliffe model efficiencies and coefficients of determination between measured runoff volume and simulated runoff volume with record-averaged soil moisture (Table 3) 
Table 3. Nash-Sutcliffe model efficiencies and coefficients of determination between measured runoff volumes and simulated runoff volumes using the long term average (2002-2010) antecedent volumetric soil moisture of $8.0 \%$ for each event as the model input.

\begin{tabular}{lllll}
\hline Watershed & $\begin{array}{l}\text { Number } \\
\text { of events }\end{array}$ & $\begin{array}{l}\text { Measured range } \\
\text { of runoff volumes }\end{array}$ & $\begin{array}{l}\text { Nash-Sutcliffe } \\
\text { model efficiency, } E\end{array}$ & $\begin{array}{l}\text { Coefficient of } \\
\text { Determination, } r^{2}\end{array}$ \\
\hline & & $\mathrm{mm}$ & & \\
\hline 63.102 & 45 & $0.1-17.1$ & 0.710 & 0.834 \\
63.103 & 46 & $0.0-20.7$ & 0.722 & 0.831 \\
63.104 & 39 & $0.0-13.1$ & 0.591 & 0.789 \\
63.106 & 56 & $0.1-22.8$ & 0.792 & 0.868 \\
\hline
\end{tabular}

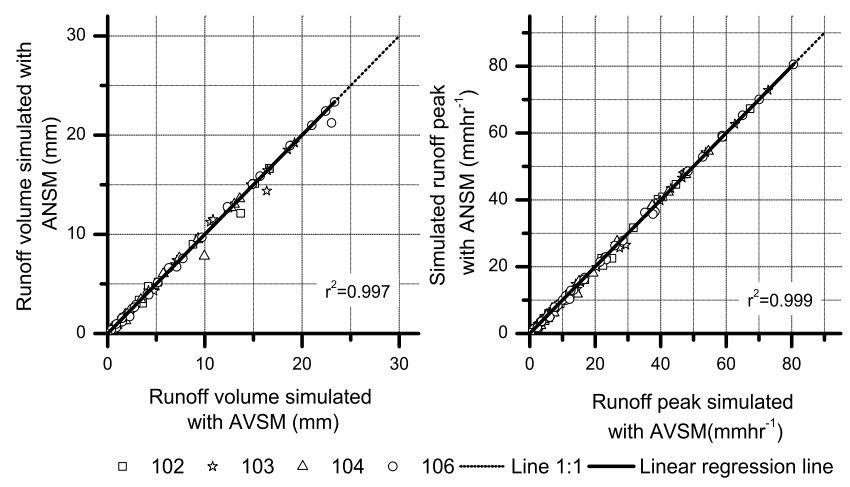

Fig. 7. Comparison of runoff volume simulated using antecedent soil moisture for each event (ANSM) and with the long-term average antecedent soil moisture (AVSM) as model input.

were only slightly less ( 0.033 and 0.022 , respectively) than the optimum possible using the measured antecedent soil moisture for each event (Table 2). Runoff depths and peak rates simulated with long term average antecedent soil moisture were statistically identical to those simulated with event measured antecedent soil moisture, with coefficients of determination between the two predictions of 0.997 and 0.999 , respectively (Fig. 7).

\section{Conclusions}

This study presents unique data on the effects of antecedent soil moisture on runoff generation in a dry-land environment, along with implications for process-based modeling of runoff. The data were collected from four small watersheds continuously over a period of nine years from 2002 through 2010 in an environment where evapo-transpiration approaches $100 \%$ of the infiltrated water on the hillslopes. Storm events are generally intense and of short duration, and antecedent volumetric moisture conditions were dry, with an average in the upper $5 \mathrm{~cm}$ soil layer over the nine year period of $8 \%$ and a standard deviation of $3 \%$. Sensitivity analysis of the model showed an average of $0.05 \mathrm{~mm}$ change in runoff generation for each $1 \%$ change in soil moisture, indicating an approximate $0.15 \mathrm{~mm}$ average variation in runoff accounted for by the $3 \%$ standard deviation of measured antecedent soil moisture. This compared to a standard deviation of $4.7 \mathrm{~mm}$ in the runoff depths for all of the measured events taken together. Thus the low variability of soil moisture in this environment accounts for the relative lack of importance of storm antecedent soil moisture for modeling the runoff.

Runoff characteristics simulated with a nine year average of antecedent soil moisture were statistically identical to those simulated with measured antecedent soil moisture, indicating that long term average antecedent soil moisture could be used as a substitute for measured antecedent soil moisture for runoff modeling of these watersheds.

We did not find a threshold value of measured antecedent soil moisture controlling the presence or absence of runoff, and there was no significant correlation $(\alpha=0.05)$ between measured runoff ratio and antecedent soil moisture in any of the four watersheds.

Further studies could be focused on the change of soil water during runoff event and the effect of antecedent soil water on the shape of the hydrographs to test the model reliability of simulating runoff process.

Acknowledgements. USDA is an equal opportunity provider and employer. The authors thank the USDA-ARS Southwest Watershed Research Center staff for their efforts in collecting the data that made this research possible.

Edited by: T. Moramarco

\section{References}

Abrahams, A. D., Parsons, A. J., and Luk, S. H.: Hydrologic and sediment responses to simulated rainfall on desert hillslopes in southern Arizona, Catena, 15, 103-117, 1988.

Brocca, L., Melone, F., and Moramarco, T.: Soil water content monitoring in an experimental basin in central Italy, Proceedings of International Conference ERB2004 Euromediterranean Conference, Torino, 18-21, 2004.

Brocca, L., Melone, F., and Moramarco, T.: Empirical and conceptual approaches for soil moisture estimation in view of event- 
based rainfall-runoff modeling, in: Progress in Surface and Subsurface Water Studies at the Plot and Small Basin Scale, edited by: Maraga, F. and Arattano, M., IHP-VI, Technical Documents in Hydrology, No. 77, Unesco: Paris, 1-8, 2005.

Brocca, L., Melone, F., and Moramarco, T.: On the estimation of antecedent wetness conditions in rainfall-runoff modeling, Hydrol. Process., 22, 629-642, 2008.

Brocca, L., Melone, F., Moramarco, T., and Morbidelli, R.: Antecedent wetness conditions based on ERS scatterometer data, J. Hydrol., 364, 73-87, doi:10.1016/j.jhydrol.2008.10.007, 2009a.

Brocca, L., Melone, F., Moramarco, T., and Singh, V. P.: Assimilation of observed soil moisture data in storm rainfall-runoff modelling, J. Hydrol. Eng., 14, 153-165, doi:10.1061/(ASCE)10840699(2009)14:2(153), 2009b.

Brocca, L., Melone, F., Moramarco, T., Penna, D., Borga, M., Matgen, P., and Heitz, S.: Investigation of the hydrologic response of three experimental basins across Europe, in: Hydrological Responses of Small Basins to a Changing Environment, edited by: Holzmann, H., Godina, R., and Muller, G., IHP-VI, Tech. Doc. Hy., UNESCO, Paris, in press, 2011a.

Brocca, L., Melone, F., and Moramarco, T.: Distributed rainfall-runoff modeling for flood frequency estimation and flood forecasting, Hydrol. Process., 25, 2801-2813, doi:10.1002/hyp.8042, 2011b.

Castillo, V. M., Gomez-Plaza, A., and Martinez-Mena, M.: The role of antecedent soil water content in the runoff response of semiarid catchments: a simulation approach, J. Hydrol., 284, 114130, 2003.

Chu, S. T.: Infiltration during an unsteady rain, Water Resour. Res., 14, 461-466, 1978.

Goodrich, D. C., Schmugge, T. J., Jackson, T. J., Unkrich, C. L., Keefer, T. O., Parry, R., Bach, L. B., and Amer, S. A.: Runoff simulation sensitivity to remotely sensed initial soil water content, Water Resour. Res., 30, 1393-1405, 1994.

Goodrich, D. C., Keefer, T. O., Unkrich, C. L., Nichols, M. H., Osborn, H. B., Stone, J. J., and Smith, J. R.: Longterm precipitation database, Walnut Gulch Experimental Watershed, Arizona, United States, Water Resour. Res., 44, W05S04, doi:10.1029/2006WR005782, 2008.

James, A. L. and Roulet, N. T.: Antecedent moisture conditions and catchment morphology as controls on spatial patterns of runoff generation in small forest catchments, J. Hydrol., 377, 351-366, 2009.

Kampf, S. K.: Variability and persistence of hillslope initial conditions: A continuous perspective on subsurface flow response to rain events, J. Hydrol., 404, 176-185, doi:10.1016/j.jhydrol.2011.04.028, 2011.

Karnieli, A. and Ben-Asher, J.: A daily runoff simulation in semiarid watersheds based on soil water deficit, J. Hydrol., 149, 9-25, 1993.

Keefer, T. O., Moran, M. S., and Paige, G. B.: Long-term meteorological and soil hydrology database, Walnut Gulch Experimental Watershed, Arizona, United States, Water Resour. Res., 44, W05S07, doi:10.1029/2006WR005702, 2008.

Martinez-Mena, M., Albaladejo, J., and Castillo, V.: Factors influencing surface runoff generation in a Mediterranean semiarid environment: Chicamo watershed, SE Spain, Hydrol. Process., 12, 741-754, 1998.

Mein, R. G. and Larson, C. L.: Modeling infiltration during a steady rain, Water Resour. Res., 9, 384-394, 1973.

Moran, M. S., Emmerich, W. E., Goodrich, D. C., Heilman, P., Holifield Collins, C. D., Keefer, T. O., Nearing, M. A., Nichols, M. H., Renard, K. G., Scott, R. L., Smith, J. R., Stone, J. J., Unkrich, C. L., and Wong, J.: Preface to special section on Fifty Years of Research and Data Collection: U.S. Department of Agriculture Walnut Gulch Experimental Watershed, Water Resour. Res., 44, W05S01, doi:10.1029/2007WR006083, 2008.

Nash, J. E. and Sutcliffe, J. V.: River flow forecasting through conceptual models part I - A discussion of principles, J. Hydrol., 10, 282-290, 1970.

Nearing, M. A. and Hairsine, P. B.: The Future of Soil Erosion Modelling. Ch. 20, in: Handbook of Erosion Modelling, edited by: Morgan, R. P. and Nearing, M. A., ISBN: 978-1-051-9010-7, pp. 416, Wiley-Blackwell Publishers, Chichester, West Sussex, UK, 387-397, 2011.

Nearing, M. A., Kimoto, A., Nichols, M. H., and Ritchie, J. C.: Spatial patterns of soil erosion and deposition in two small, semiarid watersheds, J. Geophys. Res., 110, F04020, doi:10.1029/2005JF000290, 2005.

Nearing, M. A., Nichols, M. H., Stone, J. J., Renard, K. G., and Simanton, J. R.: Sediment yields from unitm - source semiarid watersheds at Walnut Gulch, Water Resour. Res., 43, W06426, doi:10.1029/2006WR005692, 2007.

Nearing, M. A., Wei, H., Stone, J. J., Pierson, F. B., Spaeth, K. E., Weltz, M. A., and Flanagan, D. C.: A Rangeland Hydrology and Erosion Model, Transactions of the American Society of Agricultural and Biological Engineers, 54, 1-8, 2011.

Nichols, M. H. and Anson, E.: Southwest Watershed Research Center Data Access Project, Water Resour. Res., 44, W05S03, doi:10.1029/2006WR005665, 2008.

Nichols, M. H., Renard, K. G., and Osborn, H. B.: Precipitation changes from 1956-1996 on the Walnut Gulch Experimental Watershed, J. Am. Water Resour. As., 33, 161-172, 2002.

Penna, D., Tromp-van Meerveld, H. J., Gobbi, A., Borga, M., and Dalla Fontana, G.: The influence of soil moisture on threshold runoff generation processes in an alpine headwater catchment, Hydrol. Earth Syst. Sci., 15, 689-702, doi:10.5194/hess-15-6892011, 2011.

Polyakov, V., Kimoto, A., Nearing, M. A., and Nichols, M. H.: Tracing sediment movement on semi-arid watershed using Rare Earth Elements, Soil Sci. Soc. Am. J., 73, 1559-1565, 2009.

Renard, K. G., Nichols, M. H., Woolhiser, D. A., and Osborn, H. B.: A brief background on the U.S. Department of Agriculture Agricultural Research Service Walnut Gulch Experimental Watershed, Water Resour. Res., 44, W05S02, doi:10.1029/2006WR005691, 2008.

Saltelli, S. T. and Campolongo, F.: Sensitivity analysis as an ingredient of modeling, Stat. Sci., 15, 377-395, 2000.

Stone, J. J., Nichols, M. H., Goodrich, D. C., and Buono, J.: Long-term runoff database, Walnut Gulch Experimental Watershed, Arizona, United States, Water Resour. Res., 44, W05S05, doi:10.1029/2006WR005733, 2008.

Sheikh, V., v. Loon, E., Hessel, R., and Jetten, V.: Sensitivity of LISEM predicted catchment discharge to initial soil moisture content of soil profile, J. Hydrol., 393, 174-185, 2010.

Tramblay, Y., Bouvier, C., Martin, C., Didon-Lescot, J. F., Todorovik, D., and Domergue, J. M.: Assessment of initial soil moisture conditions for event-based rainfall-runoff modelling, J. Hy- 
drol., 380, 305-317, doi:10.1016/j.jhydrol.2010.04.006, 2010.

Wei, H., Nearing, M. A., and Stone, J. J.: A comprehensive sensitivity analysis framework for model evaluation and improvement using a case study of the rangeland hydrology and erosion model, Trans. Am. Soc. Agric. Eng., 50, 945-953, 2007.

Wei, H., Nearing, M. A., Stone, J. J., Guertin, D. P., Spaeth, K. E., Pierson, F. B., Nichols, M. H., and Moffett, C. A.: A New Splash and Sheet Erosion Equation for Rangelands, Soil Sci. Soc. Am. J., 73, 1386-1392, 2009.

Western, A. W., Blöschl, G., and Grayson, R. B.: The Tarrawarra data set: soil moisture patterns, soil characteristics, and hydrological flux measurements, Water Resour. Res., 34, 2765-2768, 1998.
Yair, A. and Klein, M.: The influence of surface properties on flow and erosion processes on debris covered slopes in an arid area, Catena, 1, 1-18, 1973.

Zehe, E. and Blöschl, G.: Predictability of hydrologic response at the plot and catchment scales: role of initial condition, Water Resour. Res., 40, W10202, doi:10.1029/2003WR002869, 2004.

Zehe, E., Becker, R., Bárdossy, A., Plate, E.: Uncertainty of simulated catchment runoff response in the presence of threshold processes: Role of initial soil moisture and precipitation, J. Hydrol., 315, 183-202, 2005. 